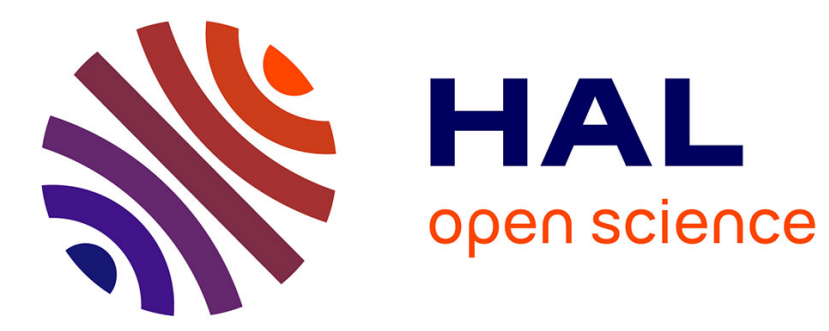

\title{
High Frequency Characteristics of Nanocrystalline Co-Fe-Hf-O Soft Magnetic Films
}

\author{
Y. Hayakawa, K. Ohminato, N. Hasegawa, A. Makino
}

\section{To cite this version:}

Y. Hayakawa, K. Ohminato, N. Hasegawa, A. Makino. High Frequency Characteristics of Nanocrystalline Co-Fe-Hf-O Soft Magnetic Films. Journal de Physique IV Proceedings, 1997, 07 (C1), pp.C1495-C1-496. 10.1051/jp4:19971202 . jpa-00254853

\section{HAL Id: jpa-00254853 https://hal.science/jpa-00254853}

Submitted on 1 Jan 1997

HAL is a multi-disciplinary open access archive for the deposit and dissemination of scientific research documents, whether they are published or not. The documents may come from teaching and research institutions in France or abroad, or from public or private research centers.
L'archive ouverte pluridisciplinaire HAL, est destinée au dépôt et à la diffusion de documents scientifiques de niveau recherche, publiés ou non, émanant des établissements d'enseignement et de recherche français ou étrangers, des laboratoires publics ou privés. 


\title{
High Frequency Characteristics of Nanocrystalline Co-Fe-Hf-O Soft Magnetic Films
}

\author{
Y. Hayakawa, K. Ohminato, N. Hasegawa and A. Makino \\ Nagaoka Branch, Central Research Laboratory, Alps Electric Co., Ltd., 1-3-5 Higashi-Takami, Nagaoka \\ 940, Japan
}

\begin{abstract}
The microstructure, electrical resistivity, and high frequency soft magnetic properties of nanocrystalline $\mathrm{Co}-\mathrm{Fe}-\mathrm{Hf}-\mathrm{O}$ films were investigated. The films were prepared by if reactive sputtering technique in $\mathrm{Ar}+\mathrm{O}_{2}$ mixed atmosphere under a static magnetic field or no field. In an as-deposited state, a $\mathrm{Co}_{44.3} \mathrm{Fe}_{19.1} \mathrm{Hf}_{14.3} \mathrm{O}_{22.1}$ film deposited in a static field consists of mixed structure of amorphous phase and bcc nanocrystals with $3-4 \mathrm{~nm}$ in diameter. The real part ( $\left.\mu^{\prime}\right)$ of complex permeability of 160 is almost constant up to $1 \mathrm{GHz}$, and extremely high $\mu^{\prime} / \mu^{\prime \prime}$ of 61 at $100 \mathrm{MHz}$ is obtained. These high frequency characteristics are caused by the high electrical resistivity $(\rho)$ of $13 \mu \Omega \mathrm{m}$ and large anisotropy field $\left(\mathrm{H}_{k}\right)$ of $4.8 \mathrm{kA} / \mathrm{m}$.
\end{abstract}

\section{INTRODUCTION}

Recently, the soft magnetic films with low losses as at high frequency have been strongly required for the improvement and miniaturization of magnetic devices such as inductors and transformers. In high frequency region, low resistivity $\rho$ of metallic alloy films gencrally result in an increase of an eddy current loss. We have been studying the high resistive Fe-M-O films (M= Hf, $\mathrm{Zr}$, Y,or Rare-Earth elements) [ $1-3$ ], whose structure is composed of nanocrystalline bcc phase ( $\leqq 10 \mathrm{~nm})$ and amorphous phase containing larger amounts of $M$ and $O$ elements than those of bcc phase. These films have several times higher $\rho$ values than conventional metallic alloy films. As a result, the $\mu$ ' of 1000 is constant up to $100 \mathrm{MHz}$ along the magnetic hard axis. However, large $\mathrm{H}_{k}$ is also required besides the high $\rho$ values to further reduce the loss factor in the high frequency range over $100 \mathrm{MHz}$.

In this study, we tried to induce a large $\mathrm{H}_{k}$ and to improve the high frequency characteristics by substituting Co for the major part of Fe of Fe-Hf-O films.

\section{EXPERIMENTAL PROCEDURE}

The films with approx. $2 \mu \mathrm{m}$ in thickness were prepared by rf reactive sputtering technique in a mixed atmosphere of $\mathrm{Ar}$ and $\mathrm{O}_{2}$ under a static magnetic field. Microstructure of the films were analyzed by a field-emission-type $200 \mathrm{kV}$ transmission electron microscope (TEM) with nano-beam electron diffraction and energy dispersive $X$-ray spectroscopy (EDX). The angular dispersion of uniaxial magnetic anisotropy $\left(\alpha_{90}\right)$ was measured using a B-H loop tracer [4]. Frequency dependence of $\mu$ ' and $\mu$ " was measured up to $1 \mathrm{GHz}$ by a parallel line technique [5].
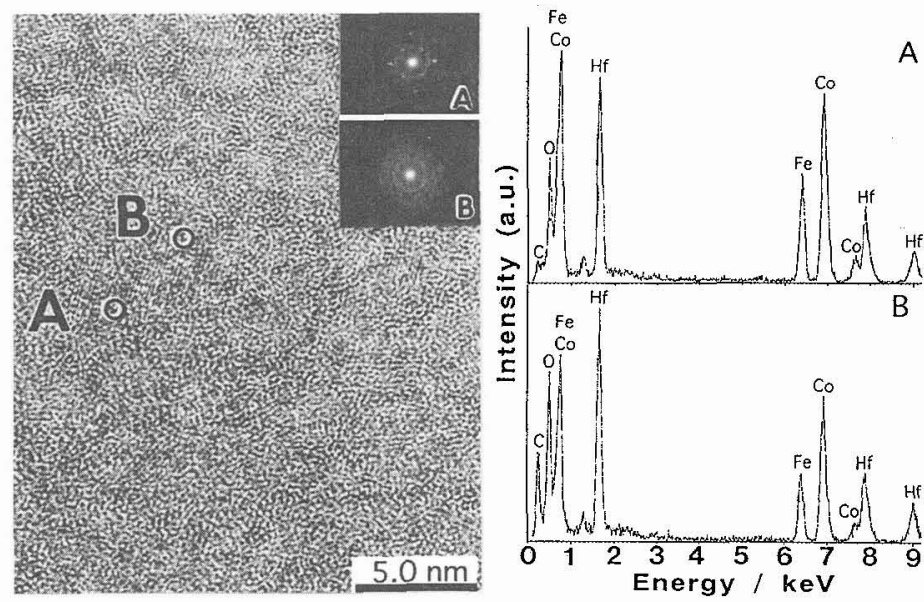

Figure 1 : High - resolution TEM image, electron diffraction patterns, and EDX spectra for an as-deposited $\mathrm{Co}_{44.3} \mathrm{Fe}_{19.1} \mathrm{Hf}_{14.3} \mathrm{O}_{22.1}$ film. 


\section{RESULTS AND DISCUSSION}

Figure 1 shows the TEM image, electron diffraction patterns, and EDX spectra of an as-deposited $\mathrm{CO}_{44,3} \mathrm{Fe}_{19,1} \mathrm{Hf}_{14.5} \mathrm{O}_{22.1}$ film. The electron diffraction patterns and the EDX spectra were taken from the region in the TEM image indicated by $\mathrm{A}$ and $\mathrm{B}$. The region $\mathrm{A}$ and $\mathrm{B}$ correspond to the crystalline phase and amorphous phase, respectively. The film is composed of crystalline phase below $4 \mathrm{~nm}$ in diameter, which is smaller than that of Fe-Hf-O films [1], and an amorphous phase surrounding them. This crystalline phase is identified as bcc phase from the electron diffraction pattern $A$. As can be seen in the EDX spectra, the peaks of $\mathrm{Hf}$ and $\mathrm{O}$ elements from the amorphous phase are stronger than those of the bcc phase. This means the amorphous phase contains larger amount of $\mathrm{Hf}$ and $\mathrm{O}$ elements. In addition, considerable amounts of $H f$ and $O$ are supersaturated in the bcc phase.

Figure 2 shows the magnetization curves along the easy and hard axis for as-deposited $\mathrm{Co}_{44.3} \mathrm{Fe}_{19.1} \mathrm{Hf}_{14.5} \mathrm{O}_{22.1}$ film compared with those of an $\mathrm{Fe}_{61} \mathrm{Hf}_{13} \mathrm{O}_{26}$ film. The magnetization curves for the magnetic easy and hard axis are indicated by $\|$ and 1 , respectively. The data of $\alpha_{90}$ are also shown in the figure. The $\mathrm{Co}_{44.3} \mathrm{Fe}_{19.1} \mathrm{Hf}_{14.5} \mathrm{O}_{22.1}$ film was deposited in a uniaxial ficld, and the $\mathrm{Fe}_{61} \mathrm{Hf}_{13} \mathrm{O}_{26}$ film was annealed at $673 \mathrm{~K}$ for $10.8 \mathrm{ks}$ under a uniaxial field of 160 $\mathrm{kA} / \mathrm{m}$ after deposition with no field. The saturation magnetization (I) of $1.1 \mathrm{~T}$ and the high $\rho$ value of $13 \mu \Omega \mathrm{m}$ are simultancously obtained for $\mathrm{Co}_{44.3} \mathrm{Fe}_{19.1} \mathrm{Hf}_{14.5} \mathrm{O}_{22.1}$ film. By substituting $\mathrm{Co}$ for the major part of $\mathrm{Fe}$, a much larger $\mathrm{H}_{\mathrm{k}}$ of $4.8 \mathrm{kA} / \mathrm{m}$ than that of the $\mathrm{Fe}_{61} \mathrm{Hf}_{13} \mathrm{O}_{26}$ film is also obtained. Consequently, the $\alpha_{90}$ becomes smaller than that of an $\mathrm{Fe}_{61} \mathrm{Hf}_{13} \mathrm{O}_{26}$ film. The relatively small $\mathrm{H}_{\mathrm{i}}$ of $440 \mathrm{~A} / \mathrm{m}$ despite the major constituent is Co which has a

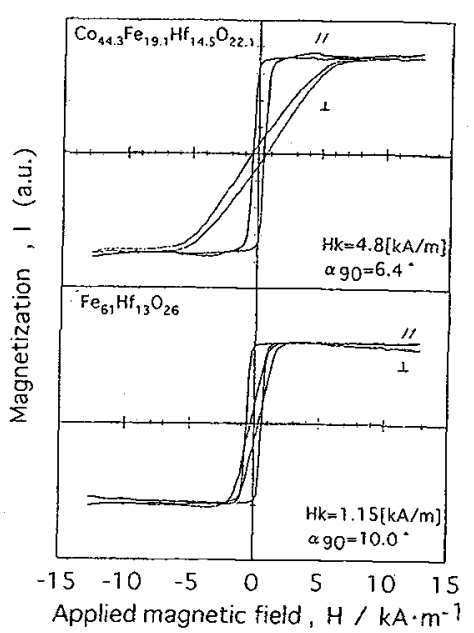
large nagnetocrystalline anisotropy, is attributed to the effect of
very small grain size [ 6$]$ below $4 \mathrm{~nm}$ as shown in Fig. 1. Accordingly, the frequency characteristics of this film expccted to be improved.

Figure 3 shows the frequency dependence of $\mu^{\prime}$ and $\mu$ " together with the calculated data (solid line), considering both eddy current loss and the resonance loss [7], for as-deposited $\mathrm{Co}_{44.3} \mathrm{Fe}_{19.1} \mathrm{Hf}_{14.5} \mathrm{O}_{22.1}$ film. For the calculation, the experimental dain such as $I_{s}, H_{k}, \rho$ and the film thickness are used as the parameter. The damping constant $\alpha$ was replaced by the data of Co based amorphous alloy film [7]. The $\mu^{\prime}$ of 160 is almost flat up to $1 \mathrm{GHz}$ and the $\mu$ "is reduced drastically. As a result, $\mathscr{Q}$ the $\mu " / \mu$ " exhibits extremely high value of 61 at $100 \mathrm{MHz}$. There are some difference between the experimental and the calculated data, however, they show better agreement near $1 \mathrm{GHz}$ than those of the other soft magnetic films. These high frequency soft magnetic characteristics are resulted from the large $\mathrm{H}_{\mathrm{k}}$ with a small dispersion of uniaxial magnetic anisotropy,

Figure 2 : Magnetization curves for an as-deposited $\mathrm{Co}_{44.3} \mathrm{Fe}_{19.1} \mathrm{Hf}_{14.5} \mathrm{O}_{22.1}$ film, and an $\mathrm{Fe}_{63} \mathrm{Hf}_{13} \mathrm{O}_{26}$ film annealed at $673 \mathrm{~K}$ for $10.8 \mathrm{ks}$ under a uniaxial magnetic field of $160 \mathrm{kA} / \mathrm{m}$.

shown in Fig. 2, and high $\rho$ value of $13 \mu \Omega \mathrm{m}$. Therefore, this film has high potential for high frequency applications, such as micro magnetic devices, owing to the magnetically low loss properties in the high frequency region.

\section{References}

[1] A. Makino and Y. Hayakawa, J. Jpn. Inst. Met. 57 (1993) $1301-1309$.

[2] A. Makino and Y. Hayakawa, Mater. Sci. Eng. A181/A182 (1994) 1020 - 1024.

[3] Y. Hayakawa and A. Makino, NanoStructured Mater. 6 (1995) 989 - 992.

[4] T. S. Crowther, J. Appl. Phys. 34 (1963) 580 - 587.

[5] T. Kimura, M. Mitera, S. Terasaka, M. Nose, F. Matsumoto, H. Matsuki, H. Fujimori and T. Masumoto, J. Magn. Soc. Jpn. 17 (1993) $497 \sim 502$.

[6] G. Herzer, IEEE Trans. Magn, 26 (1990) 1397 - 1402.

[7] A. Hosono and Y. Shimada, J. Magn. Soc. Jpn. 12 (1988) 295 - 298. 